\title{
Effect of Potassium on Potato Tuber Production in Acid Soils of Malepatan, Pokhara
}

\author{
Bishnu H. Adhikary*1 and Krishna B. Karki ${ }^{2}$ \\ ${ }^{1}$ National Maize Research Programme-NARC-Rampur-Chitwan-Nepal \\ ${ }^{2}$ Soil Science Division-Khumaltar-Lalitpur-Nepal
}

\begin{abstract}
Soils of Pokhara valley, especially Malepatan, are fine textured silt loam, extremely acidic in nature $(3.7-4.0 \mathrm{pH})$ and are medium in soil potassium content. On-station experiments were conducted to assess the response of potassium $\left(\mathrm{K}_{2} \mathrm{O}\right)$ and its application methods on potato tuber yield in an extremely acid soil condition. Six potassium levels $\left(0,50,75,100 \mathrm{~kg} \mathrm{ha}^{-1}\right.$ as basal application, $50 \mathrm{~kg}$ basal plus $50 \mathrm{~kg}$ top dressed, and $50 \mathrm{~kg}$ basal plus $50 \mathrm{~kg}$ foliar application) were tested in the experiment for three consecutive years (2000, 2001 and 2002). A randomized complete block design (RCBD) with 3 replications was employed. Variety used was MS 42. Nitrogen $(\mathrm{N})$, phosphorus $\left(\mathrm{P}_{2} \mathrm{O}_{5}\right)$ and compost were applied as basal dose in each plots at the rate of $100 \mathrm{~kg}, 50 \mathrm{~kg}$ and $20 \mathrm{t} \mathrm{ha}^{-1}$, respectively. Three years mean result on the plant growth characters revealed that tallest plant height was recorded $(33.22 \mathrm{~cm})$ when $50 \mathrm{~kg} \mathrm{ha}^{-1}$ potassium was applied basally and $50 \mathrm{~kg} \mathrm{ha}^{-1}$ top-dressed. The trend was quite similar in tillers production (6.96 branches plant ${ }^{-1}$ ) and biomass production $\left(168.66 \mathrm{~g} \mathrm{plant}^{-1}\right)$. Maximum of $473.33-\mathrm{g} \mathrm{plant}^{-1}$ of tubers was produced when $100 \mathrm{~kg}$ of potassium was applied basal single dose. Highest tuber yield of $24.75 \mathrm{t} \mathrm{ha}^{-1}$ of tuber were produced when $50 \mathrm{~kg}$ potassium was applied basally and 50 $\mathrm{kg}$ top- dressed, a total of $100 \mathrm{~kg} \mathrm{ha}^{-1}$. Highly significant response of potassium levels on tuber production was observed in all the years. The results of this investigation suggested that application of potassium $\left(\mathrm{K}_{2} \mathrm{O}\right)$ at the rate of $50 \mathrm{~kg} \mathrm{ha}^{-1}$ basal and $50 \mathrm{~kg} \mathrm{ha}^{-1}$ top-dressed in 45 days could increase potato tuber yield satisfactorily in extremely acid soil condition.
\end{abstract}

Key words: Basal application, potassium levels, Solanum tuberosum, tuber production and topdressing

\section{INTRODUCTION}

Potato (Solanum tuberosum L.) is one of the most important crops for Nepalese people. It is grown from the terai to the high mountain region. Because the food produced through photosynthesis in plant leaves needs in translocation and synthesis of carbohydrates to form tuber this crop, including other essential elements needs higher amount of potassium (Mengel and Rahmatullah 1994). In addition this element is needed to resist cold and other adverse conditions by plants. Deficient potato and Brassica plants develop crumpled and raised lamina followed by necrosis (Singh et al 1997). Nepalese soils due to its high in silt content are high in available Potassium K (Schrier et al 1994). But continues cropping nutrient exhausting crop mine soil nutrients and farmers do not replenish the harvested nutrients (Joshi 1997) that lead to serious nutrient deficiency and reduction in crop yield (Ghani and Brown 1997, Gami et al 2001, Regmi et al 2002).

Potassium (K) in soil is present in three different forms that is total $\mathrm{K}$, exchangeable and $\mathrm{K}$ in soil solution (Mengel and Kirkby 1987). Soil solution K has a high chance of leaching and thus loss from the soil system. Exchangeable K plays an important role in soil plant availability. Potassium from mica as dominant mineral in Nepalese soil (Schrier et al 1994) and K from mica contributes a part of soil potassium (Mengel and Rahmatullah 1994, Baeumler et al 1997). Because of low replenishment widespread deficiency of potassium has been reported in many of the intensively cultivated soils (Karki 
et al 2000) and hence $\mathrm{K}$ application through fertilisers has been responding satisfactorily (Regmi et al 2002). Potato being a high nutrient mining crop it needs higher amount of $\mathrm{N}, \mathrm{P}$ and $\mathrm{K}$ for its economic tuber production. Farmers applying 20-25 $\mathrm{t} \mathrm{ha}^{-1}$ of compost/farmyard manure are not sufficient to replenish the harvested nutrients and hence need sufficient amount of mineral fertilizer addition with heavy manure application (Joshi 1997). Despite of application of sufficient amount of $\mathrm{N}$ and $\mathrm{P}_{2} \mathrm{O}_{5}$ fertiliser lack of potassium has limited yield in Indo Gangatic Plains (IGP) of Nepal and India (Gami et al 2001, Regmi et al 2002). Therefore, we conducted this experiment with the objectives of evaluating the response of potassium through different methods of application on the tuber production of potato was.

\section{MATERIALS AND METHODS}

Experiment was conducted in Agricultural Research Station (ARS), Pokhara in extremely acid soils (3.7- $4.0 \mathrm{pH}$ ) of Malepatan Soil during the year 2000 to 2002 to. The experiment was designed in a randomized complete block design (RCBD) with 3 replications. The variety used was MS-42 and the crop was planted in the month of November in all the years with a spacing of $25-\times 75-\mathrm{cm}$ in a plot size of $12.187 \mathrm{~m}^{2}(3.25-\times 3.75-\mathrm{m})$. All amount of $\mathrm{N}, \mathrm{P}_{2} \mathrm{O}_{5}$ and compost were applied basally at the rate of $100 \mathrm{~kg}, 50 \mathrm{~kg}$ and $20 \mathrm{t} \mathrm{ha}^{-1}$, respectively. Soil samples were taken before crop planting and after crop harvest to observe $\mathrm{K}_{2} \mathrm{O}$ status in the soil. Plant growth and production parameters were studied and analysed statistically (Gomez and Gomez 1984). The following treatments were applied in the experiment:

$\mathrm{T} 1=50 \mathrm{~kg} \mathrm{ha}^{-1}$ potassium $\left(\mathrm{K}_{2} \mathrm{O}\right)$ applied as basal dose.

$\mathrm{T} 2=75 \mathrm{~kg} \mathrm{ha}^{-1}$ potassium applied as basal dose.

$\mathrm{T} 3=100 \mathrm{~kg} \mathrm{ha}^{-1}$ potassium applied basal.

$\mathrm{T} 4=100 \mathrm{~kg} \mathrm{ha}^{-1}$ potassium (50 kg basal and $50 \mathrm{~kg}$ top-dressed in 45 days after seeding).

$\mathrm{T} 5=0 \mathrm{~kg}$ potassium (control plot).

$\mathrm{T} 6=100 \mathrm{~kg} \mathrm{ha}^{-1}$ potassium (50 kg basal and $50 \mathrm{~kg}$ sprayed in 45 days after seeding ie $0.5 \%$ solution).

Collected soil samples were air dried and passed through $2 \mathrm{~mm}$ sieve and stored for analysis. Soil $\mathrm{pH}$ was measured in soil water paste ration of 1:2.5 and measured with combined glass electrode. Nitrogen was analyzed by Micro-Kjeldahl methods and available $\mathrm{P}_{2} \mathrm{O}_{5}$ by Bray P-1 method. Available $\mathrm{K}$ was extracted by $1 \mathrm{~N}$ neutral ammonium acetate solution and detected through flame ignition.

\section{RESULTS}

\section{Effect of potassium levels on the growth of potato plants}

Three years results on plant growth characters clearly indicated that mean plant height was maximum $(33.23 \mathrm{~cm})$ in $\mathrm{T} 4$ when the crop was fertilized with $100 \mathrm{~kg} \mathrm{ha}^{-1}$ potassium $(50 \mathrm{~kg} \mathrm{~K} 2 \mathrm{O}$ basal and $50 \mathrm{~kg}$ top-dressed in 45 days). Minimum plant height $(26.6 \mathrm{~cm})$ was found in T5 (control). The numbers of tiller and crop biomass expressed almost similar trend. The maximum number of tillers (9.96) was produced in T4 and minimum (5.21) was in T5. The biomass (121.33 $\mathrm{g}$ plant $^{-1}$ ) was highest in T4 control was $121.33 \mathrm{~g} \mathrm{plant}^{-1}$ (Table 1).

Application of $100 \mathrm{~kg} \mathrm{ha}^{-1}$ of potassium applied as basal dose (T3) produced maximum tuber weight (473.33 $\left.\mathrm{g} \mathrm{plant}^{-1}\right)$, followed by T4 $\left(50+50 \mathrm{~kg} \mathrm{ha}^{-1}\right), \mathrm{T} 2\left(75 \mathrm{~kg} \mathrm{ha}^{-1}\right.$ basal dose only) and T1 $\left(50 \mathrm{~kg} \mathrm{ha}^{-1}\right)$. Minimum tuber weight (314 $\left.\mathrm{g} \mathrm{plant}^{-1}\right)$ was recorded in control plot (T5). The treatment T4 (50 kg basal $+50 \mathrm{~kg} \mathrm{ha}^{-1}$ as top dressed) produced slightly lower tuber yield (461.66 $\mathrm{g} \mathrm{plant}^{-1}$ ) than T3. Application of $50 \mathrm{~kg} \mathrm{ha}^{-1} \mathrm{~K}$ (T1) produced $369 \mathrm{~g}$ plant $^{-1}$ of potato tubers that is higher than the control, whereas its application as T6 $\left(50 \mathrm{~kg} \mathrm{ha}^{-1}\right.$ basal and $50 \mathrm{~kg} \mathrm{ha}^{-1}$ as foliar spray) produced the tuber yield of $403.66 \mathrm{~g}$ 
plant $^{-1}$ (T6) that is much higher than the control (T5). There was note worthy difference in the yield and other agronomic properties of the plant but the results were not statistically significant.

Table 1. Growth characters of potato plants as influenced by potassium levels and application methods (2000/02)

\begin{tabular}{lrrrr}
\hline Treatment & Plant height, $\mathrm{cm}$ & Tiller numbers plant $^{-1}$ & Biomass plant $^{-1}, \mathrm{~g}$ & Tuber weight plant $^{-1}, \mathrm{~g}$ \\
\hline T1 & 28.75 & 5.80 & 134.00 & 369.00 \\
T2 & 31.08 & 6.33 & 148.33 & 417.66 \\
T3 & 31.43 & 6.43 & 156.00 & 473.33 \\
T4 & 33.23 & 6.96 & 168.66 & 461.66 \\
T5 & 26.60 & 5.21 & 121.33 & 314.00 \\
T6 & 29.36 & 6.33 & 162.33 & 403.66 \\
\hline Mean & 30.07 & 6.17 & 148.44 & 406.55 \\
SD & 2.12 & 0.54 & 16.34 & 54.16 \\
\hline
\end{tabular}

\section{Effect of potassium levels on tuber production}

Analyzing the size of potato tubers (diameter) the result in first year (year 2000) was not significant. The data revealed that significant response of $\mathrm{K}_{2} \mathrm{O}$ levels on tuber diameter was observed in the years 2001 and 2002 (Table 2). The maximum 3 years mean result on tuber size (diameter) was recorded in T3 $(5.12 \mathrm{~cm})$ when the crop was treated with $100 \mathrm{~kg} \mathrm{ha}^{-1}$ of basal application of $\mathrm{K}_{2} \mathrm{O}$, whereas the control (T5) produced the minimum diameter $(4.62 \mathrm{~cm})$. Three years results on the production of tuber numbers (Table 2) indicated a sharp response on $\mathrm{K}_{2} \mathrm{O}$ levels in the first and second years (2000 and 2001) but the result was at par with the control in the third year (2002). The mean result showed that highest number of tubers (13.72 tubers plant ${ }^{-1}$ ) was produced when the crop was fertilized with $100 \mathrm{~kg}$ basal application of $\mathrm{K}_{2} \mathrm{O}$ (T3) followed by $50 \mathrm{~kg}$ basal plus $50 \mathrm{~kg}$ top-dressed $\mathrm{K}_{2} \mathrm{O}$ (T4). Control treatments (T5) produced minimum number of tubers (10.24 tuber). The yield results of the other two years were significant.

Table 2. Growth of potato tubers as affected by potassium levels and application methods for three consecutive years $(\mathbf{2 0 0 0 / 0 2})$

\begin{tabular}{lrrrrrrrr}
\hline Treatment & \multicolumn{3}{c}{ Tuber diameter, $\mathrm{cm}$} & \multirow{2}{*}{$\begin{array}{c}\text { Mean } \\
\end{array}$} & 2000 & 2001 & 2002 & \multicolumn{3}{c}{ Tuber number plant $^{-1}$} & $\begin{array}{c}\text { Means of tuber } \\
\text { number plant }\end{array}$ \\
\hline T1 & 3.31 & 4.18 & 6.62 & 4.70 & 9.76 & 12.36 & 12.26 & 11.46 \\
T2 & 3.35 & 4.47 & 6.72 & 4.84 & 10.73 & 14.66 & 11.96 & 12.45 \\
T3 & 3.69 & 4.61 & 7.08 & 5.12 & 11.90 & 15.86 & 13.40 & 13.72 \\
T4 & 3.51 & 4.66 & 7.10 & 5.09 & 10.93 & 15.50 & 13.36 & 13.26 \\
T5 & 3.54 & 3.77 & 6.55 & 4.62 & 8.83 & 10.23 & 11.66 & 10.24 \\
T6 & 3.48 & 4.67 & 7.04 & 5.06 & 10.96 & 14.93 & 13.06 & 12.98 \\
\hline Mean & 3.48 & 4.39 & 6.85 & 4.90 & 10.51 & 13.92 & 12.61 & 12.35 \\
F-test & $\mathrm{ns}$ & $* *$ & $*$ & & $* *$ & $* *$ & $\mathrm{~ns}$ & \\
CV, \% & 6.47 & 4.72 & 4.15 & & 2.51 & 6.23 & 13.0 & \\
LSD $(0.05)$ & - & 0.536 & 0.507 & & 0.684 & 2.245 & - & \\
\hline
\end{tabular}

** Significant at 0.01 level. * Significant at 0.05. ns, Non significant.

Highly significant response of $\mathrm{K}_{2} \mathrm{O}$ was observed in all the years on the production of tuber weights. The yield results indicated that a maximum of $28.96 \mathrm{t} \mathrm{ha}^{-1}$ and $25.18 \mathrm{t} \mathrm{ha}^{-1}$ of tubers were produced in the first and second year, respectively (Table 3). Maximum yield was obtained when the crop was supplied with $100 \mathrm{~kg} \mathrm{ha}^{-1}$ of basal $\mathrm{K}_{2} \mathrm{O}$ (T3) in first two years but in the $3^{\text {rd }}$ year (2002), the maximum production (23.51 tha ${ }^{-1}$ ) was recorded with the application of $50 \mathrm{~kg}$ basal +50 top-dressed $\mathrm{K}_{2} \mathrm{O} \mathrm{kg} \mathrm{ha}{ }^{-1}$ (T4). 
Table 3. Potato tuber production as influenced by potassium levels and application methods for three consecutive years $(\mathbf{2 0 0 0 / 0 2})$

\begin{tabular}{|c|c|c|c|c|c|}
\hline \multirow[t]{2}{*}{ Treatment } & \multicolumn{3}{|c|}{ Tuber production, $\mathrm{t} \mathrm{ha}^{-1}$} & \multirow[t]{2}{*}{3 years mean, $\mathrm{t} \mathrm{ha}^{-1}$} & \multirow[t]{2}{*}{ Increment, $\%$} \\
\hline & 2000 & 2001 & 2002 & & \\
\hline T1 & 24.44 & 20.46 & 13.15 & $19.60 \mathrm{bc}$ & 17.85 \\
\hline $\mathrm{T} 2$ & 25.72 & 22.42 & 17.07 & $21.73 \mathrm{ab}$ & 30.66 \\
\hline $\mathrm{T} 3$ & 28.96 & 25.18 & 19.90 & $24.68 \mathrm{a}$ & 48.40 \\
\hline $\mathrm{T} 4$ & 26.99 & 23.77 & 23.51 & $24.75 \mathrm{a}$ & 48.80 \\
\hline T5 & 21.90 & 15.32 & 12.69 & $16.63 \mathrm{c}$ & 00.00 \\
\hline T6 & 27.35 & 23.19 & 16.57 & $22.36 \mathrm{ab}$ & 34.45 \\
\hline Mean & 25.89 & 21.72 & 17.14 & 21.62 & \\
\hline F-test & $* *$ & * & $* *$ & $* *$ & \\
\hline $\mathrm{CV}, \%$ & 2.89 & 9.03 & 14.97 & 6.00 & \\
\hline LSD $(0.05)$ & 1.93 & 5.07 & 6.66 & 3.36 & \\
\hline
\end{tabular}

Means in a column with the common letter(s) are not significantly different at $5 \%$ level of significance.

Three years mean yield result indicated a sharp response of $\mathrm{K}_{2} \mathrm{O}$ on tuber production (Table 3). Highest yield result $\left(24.73 \mathrm{tha}^{-1}\right)$ was obtained with $\mathrm{T} 4(50 \mathrm{~kg}$ basal and $50 \mathrm{~kg}$ top dressed) followed by $\mathrm{T} 3$ $\left(24.68 \mathrm{~kg} \mathrm{ha}^{-1}\right)$ that was $100 \mathrm{~kg}$ basal application of $\mathrm{K}$. Third highest yield result was obtained from T6 (50 basal and $50 \mathrm{~kg} \mathrm{ha}^{-1}$ spraying) basal application. Control produced the lowest yield (16.63 $\mathrm{kg} \mathrm{ha}^{-1}$ ). The treatment T1 $\left(50 \mathrm{~kg} \mathrm{ha}^{-1}\right)$ basal application yielded slightly superior yield than the control. The maximum of potato tubers were produced when the crop was fertilized with $50 \mathrm{~kg} \mathrm{~K}_{2} \mathrm{O} \mathrm{ha}{ }^{-1}$ as basal application and $50 \mathrm{~kg} \mathrm{ha}^{-1}$ top-dressed (T4) but the yield was at par with T3 (100 kg kg ha-1 single dose) and T6. Non-significant difference yield results were observed among T1, T2 and T6. But these treatments produced tuber yield that is significantly different from control. The yield results from control treatment was inferior to T2, T3, T4 and T6 indicating there was no different among the application of $50 \mathrm{~kg} \mathrm{ha}^{-1} \mathrm{~K}_{2} \mathrm{O}$ as good as no application of potassium fertiliser. Similarly $100 \mathrm{~kg}$ basal or 50:50 carries the same meaning.

Application of $50 \mathrm{~kg} \mathrm{ha}^{-1}$ basal $\mathrm{K}_{2} \mathrm{O}$ to potato increased tuber yield by $17.85 \%$ over the non-treated crop whereas the highest increment $(48.8 \%)$ was observed when the crop was supplied with $100 \mathrm{~kg} \mathrm{ha}^{-1} \mathrm{~K}_{2} \mathrm{O}$ (50 kg basal and $50 \mathrm{~kg}$ top-dressed in 45 days).

Table 4. Soil test results before crop planting and after crop harvesting

\begin{tabular}{lrrrrrr}
\hline Treatments & $\mathrm{PH}$ & $\mathrm{OM}, \%$ & $\mathrm{~N}, \%$ & $\mathrm{P}_{2} \mathrm{O}_{5}, \mathrm{~kg} \mathrm{ha}^{-1}$ & $\mathrm{~K}_{2} \mathrm{O}, \mathrm{kg} \mathrm{ha}^{-1}$ & $\mathrm{~K}_{2} \mathrm{O}, \mathrm{kg} \mathrm{ha}^{-1}$ \\
\hline T1 & 3.96 & 3.26 & 0.127 & 129.33 & 265.66 & $(437.33)$ \\
T2 & 4.00 & 3.61 & 0.137 & 95.00 & 242.66 & $(561.66)$ \\
T3 & 4.06 & 3.70 & 0.154 & 130.66 & 224.33 & $(438.33)$ \\
T4 & 4.00 & 3.88 & 0.165 & 63.66 & 209.33 & $(658.66)$ \\
T5 & 4.03 & 3.70 & 0.138 & 58.66 & 278.33 & $(331.00)$ \\
T6 & 3.70 & 3.79 & 0.154 & 70.00 & 216.00 & $(558.33)$ \\
\hline Mean & 3.95 & 3.65 & 0.145 & 91.21 & 239.38 & $(497.55)$ \\
\hline
\end{tabular}

The numbers in the parenthesis indicate the soil test values after the crop harvest.

Six composite soil samples from the experimented plots combining the soil samples from the replicated plots were collected before crop planting and analyzed for the soil $\mathrm{pH}$, organic matter $(\mathrm{OM}) \mathrm{N}, \mathrm{P}_{2} \mathrm{O}_{5}$, and $\mathrm{K}_{2} \mathrm{O}$ content. Soil test result indicated that soil reaction $(\mathrm{pH})$ of the experimental plots was extremely acidic. According to soil test report, mean $\mathrm{pH}$ value was found to be $3.95 \mathrm{pH}$. The $\mathrm{pH}$ value ranged from 3.7 to 4.06 (Table 4). Organic matter (OM) content varied from 3.26 -3.88 percent. The mean OM content was observed to be 3.65 percent. Phosphorus $\left(\mathrm{P}_{2} \mathrm{O}_{5}\right)$ content were observed to be high $\left(58.66-130.66 \mathrm{~kg} \mathrm{ha}^{-1}\right)$, while the nitrogen $(0.127$ to $0.165 \% \mathrm{~N})$ and potassium content (209.33 to $278.33 \mathrm{~kg} \mathrm{ha}^{-1} \mathrm{~K}_{2} \mathrm{O}$ ) were observed to be medium in the soils of experimental plots before crop planting. Adhikary et al (2003) analyzed soil samples of Malepatan during the year 1995 and reported that the soil potassium content was found to be medium (150 to $237 \mathrm{~kg} \mathrm{~K}_{2} \mathrm{O} \mathrm{ha}{ }^{-1}$ ), which agreed with the soil 
analysis report of this investigation (216.0 to $278.33 \mathrm{~kg} \mathrm{~K}_{2} \mathrm{O} \mathrm{ha}{ }^{-1}$ ). In another experiment, Adhikary et al (2004) reported that the $\mathrm{K}_{2} \mathrm{O}$ content of Malepatan soil was found to be high (292.33 to $524.0 \mathrm{~kg} \mathrm{~K}_{2} \mathrm{O}$ $\left.\mathrm{ha}^{-1}\right)$.

Soil samples were also analyzed after crop harvesting for the $\mathrm{K}_{2} \mathrm{O}$ content. The results revealed that the soil potassium content was observed to be high $\left(658 \mathrm{~kg} \mathrm{~K}_{2} \mathrm{O} \mathrm{ha}{ }^{-1}\right)$ in the plots treated with $100 \mathrm{~kg} \mathrm{ha}^{-1}$ $\mathrm{K}_{2} \mathrm{O}$, applied as $50 \mathrm{~kg}$ basal dose and $50 \mathrm{~kg}$ as top-dressing. Lowest $\mathrm{K}_{2} \mathrm{O}$ content $\left(331 \mathrm{~kg} \mathrm{ha}^{-1}\right)$ was recorded in the plot where the crop was not fertilized with potassium (T5) followed by the crop supplied only with $50 \mathrm{~kg} \mathrm{ha}^{-1}$ of $\mathrm{K}_{2} \mathrm{O}$ (T1) applied basally $\left(437.33 \mathrm{~kg} \mathrm{ha}^{-1}\right)$.

\section{DISCUSSION}

Effect of $\mathrm{K}$ fertilisers on the agronomic character of potato is clearly seen as exposed by the plant growth, tuber number and tuber weight per plant by the application of $100 \mathrm{~kg}$ of $\mathrm{K}_{2} \mathrm{O} \mathrm{kg}$ ha? either as single dose or split dose. It is because of the total amount of $\mathrm{K}$ required by the plant. In general, potato tubers are planted in November and dry spell generally start from this month. If irrigation is not supplied yield drastically reduces when $\mathrm{K}_{2} \mathrm{O}$ is limited. Treatment $\mathrm{T} 3$ and $\mathrm{T} 4$ has sufficient amount of $\mathrm{K}$ that is required for controlling evapo-transpiration and translocation of glucose from leaf to the different parts of the plant body (Mengel and Kirkby 1987). The effect of fertilisers on the agronomic growth and difference made by the treatments shows that the application of $\mathrm{K}$ fertiliser alone made no difference. The Malepatan soil is silt dominated (Karki et al 2005). Light soil with higher amount of silt contains mica and it is the parent materials for K and releases slowly available to the plants (Schrier et al 1994). It could be in combination with the compost including $\mathrm{N}$ and $\mathrm{P}$ allied (Tsuno and Fujise 1998). It is mainly the $20 \mathrm{t} \mathrm{ha}^{-1}$ organic manure application all the three years has built soil organic matter that hold up the released $\mathrm{K}$ from leaching and supplied continuously at the time required by the plants (Mengel and Kirkby 1987). Compost contains about $2 \%$ total $\mathrm{K}$ and could be mineralised and add to the available $\mathrm{K}$ in soil (Karki 2004).

Size of the tuber as affected by the application of potassium fertiliser is normal because of the function of $\mathrm{K}$ is to translocate the carbohydrates from the place of photosynthesis to the tuber. The increase of size of the tuber could not only the effect of potassium fertilizer but also the combination of $\mathrm{N}, \mathrm{P}_{2} \mathrm{O}_{5}$ and high dose of organic manure (Davenport et al 1999).

Potassium is a mobile element and does not remain in soil for long after released from the reserve. Soil solution $\mathrm{K}$ either is fixed in clay lattice, or exchanged with $\mathrm{NH}^{+1}$ ions in a exchange complex. Higher rate of application of $\mathrm{K}$ fertiliser has higher chances of fixation than application of little $\mathrm{K}$ (Schneider 1997). When it in the solution it could be leached down to the subsurface horizon and is unavailable to plant (Wulf et al 1998) and leaching occurs mainly in winter. However, K leached to sub-surface horizon is not permanently lost but is accessible to plant roots up to the depth of $60 \mathrm{~cm}$. But the response of potato to split application of $\mathrm{K}$ fertilisers was higher and especially to praying after 45 days of transplanting because of loss through leaching is minimized and uptake of $\mathrm{K}$ through stomata could have avail the required $\mathrm{K}$ since potato plants needs $\mathrm{K}$ supply continuously to transport photosynthates to the tubers and hence spraying of K yielded higher yield of potato tubers (Rao and Rao 2000).

There has been no remarked difference in the residual effect of the treatments on $\mathrm{pH}$. There is noteworthy increased in organic matter content in the soil after the experiment. Treatment with higher amount of $\mathrm{K}$ application has increased the soil $\mathrm{K}$ content in all the three years. It is proportional to applied K (Wulf et al 1998). Moreover, release of non-exchangeable $\mathrm{K}$ could have increased the available $\mathrm{K}$ since, mica being the one of the component of silt and contributing total $\mathrm{K}$ that is could be positively correlated to mica and clay content in soil texture (Han et al 1999). Similar trend is also observed in total $\mathrm{N}$ content but the $\mathrm{P}$ did not show a definite trend. Increased trend in residual $\mathrm{K}$ even in 
control treatments could be due to the mineralization of organic manure that has been applied in all the treatments as well as the silt fraction of the soil texture. Gurung and Sherchan (1993) and Schrier et al 1994, made similar observations. Repeated application of organic manure results in build up of soil organic matter associated increased nutrient release over time and available $\mathrm{K}$ is positively correlated to organic carbon (Singh et al 1997). Random trend shown in phosphorus content soil after the third crop harvest could be due to fixation of $\mathrm{P}$ in acidic soils with $\mathrm{Al}^{+3}, \mathrm{Fe}^{+3}, \mathrm{Zn}^{+2}, \mathrm{Mn}^{+2}$ and $\mathrm{Cu}^{+2}$. Soil test value of $\mathrm{K}$ in this experiment is found higher if $\mathrm{K}$ application is withheld just because of soil residual $\mathrm{K}$ is higher it might fall sharply (Wulf et al 1998).

The results of this investigation concluded that plant height, branch numbers and biomass of the potato crops were found increased when the $\mathrm{K}_{2} \mathrm{O}$ was supplied at the rate $50 \mathrm{~kg}$ basal and $50 \mathrm{~kg}$ top-dressed, a total of $100 \mathrm{~kg} \mathrm{~K}_{2} \mathrm{O} \mathrm{ha}^{-1}$. Tuber size and their numbers plant ${ }^{-1}$ were found affected by the $\mathrm{K}_{2} \mathrm{O}$ levels and its applications methods. A maximum tuber diameter of $5.12 \mathrm{~cm}$ and 13.72 tuber numbers were observed when the crop was fertilized with $100 \mathrm{~kg}$ basal application of potassium. The highest tuber weight $\left(24.75 \mathrm{t} \mathrm{ha}^{-1}\right)$ was produced when the crop was fertilized with $100 \mathrm{~kg} \mathrm{~K}_{2} \mathrm{O} \mathrm{ha}^{-1}, 50 \mathrm{~kg}$ basally applied and the other $50 \mathrm{~kg}$ top-dressed. It seems that the potassium when top-dressed could produce increased tuber yield in acid soil condition. Application of $100 \mathrm{~kg} \mathrm{~K}_{2} \mathrm{O} \mathrm{ha}{ }^{-1}, 50 \mathrm{~kg}$ as basal application and another $50 \mathrm{~kg}$ as top-dressing after 45 days of crop planting, applied along with $100 \mathrm{~kg} \mathrm{~N}, 50 \mathrm{~kg}$ $\mathrm{P}_{2} \mathrm{O}_{5}$ and $20 \mathrm{t} \mathrm{ha}^{-1}$ of compost is recommended for increased tuber yield of potato in extremely acidic soil condition of Pokhara valley.

\section{ACKNOWLEDGEMENTS}

The authors wish to express their heartfelt thanks to Nepal Agricultural Research Council for supporting with funds for this research. Special thank goes to Dr SL Maskey, Soil Science Division-NARC, Khumaltar for her help and support for soil analysis and Dr MS Ghale for encouragement and moral support and C Adhikari for collecting data.

\section{REFERENCES}

Adhikary BH, BB BC and P Bhattarai. 2003. Economics of nitrogen application on cauliflower (Brassica oleracea var. botrytis) production in acid soil of Pokhara valley. In: Proc. of the Third National Horticultural Research Workshop. Horticulture Research Division, Nepal Agricultural Research Council (NARC), Khumaltar, Lalitpur, 7-8 June, 2000. Pp. 36-40.

Adhikary BH, C Adhikary, SP Dahal, DB Ranabhat and MS Ghale. 2004. Growth and production of pineapple as affected by manure and fertilizer levels. In: Proc. of the Fourth National Workshop on Horticulture Advances of Horticulture Research in Nepal. Nepal Agricultural Research Council (NARC)-NARI and Horticulture Research Division, Khumaltar, Lalitpur, 2-4 March 2004. Pp. 75-79.

Baeumler R, DP Madhikarmi and W Zech. 1997. Fine silt and clay mineralogical changes of a soil chronosequence in the Langtang valley (central Nepal). Z. Pflanzenern. Bodenk. 160: 413-421.

Davenport JR, EM Bentley and KM Whiteley. 1999. Potassium fertilizers and potato yield and quality in the Columbia Basin. In: Proc. $38^{\text {th }}$ American Washington State Potato conference and Trade shows, Moses Lake, Washington, 2-4 Feb 1999. Pp. 137-143.

Gami SK, JK Ladha, H Pathak, MP Shah, E Pasuquin, SP Pamde, PR Hobbs; D Joshy and R Mishra. 2001. Longterm changes in the yield and soil fertility status in 20 year rice-wheat experiment in Nepal. Biol. Fertil. Soils 34:73-78.

Ghani A and MW Brown. 1997. Improvement of Soil Fertility in Nepal Through Balanced Application of Fertiliser. AgResearch. Hamilton, New Zealand. A Study Report for Ministry of Foreign Affairs and Trade. Govt of New Zealand.

Gomez KA and AA Gomez 1984. Statistical procedures for agriculture research ( $2^{\text {nd }} \mathrm{ed}$ ). An International Rice Research Book. Wiley Interscience Publication, John Wiley and Sons, New York. 680 pp. 
Gurung GB and DP Sherchan. 1993. Study on the effect of long-term application of compost and chemical fertilisers on crop yields and physicochemical properties of soil on rice-wheat - cropping pattern. Working Paper No 87. Pakhribas Agriculture Station. 6 pp.

Han J, K Egashira and JL Han. 1999. Potassium status and fertility evaluation of major upland soils in northeastern part of China. Faculty of Agriculture, Kyushu University. Science Bulletin 54:77-83.

Joshi D. 1997. Soil fertility and fertilizer use in Nepal. Soil Science Division, Nepal Agricultural Research Council (NARC), Khumaltar, Lalitpur, Nepal. 82 pp.

Karki KB, A Mentler and WEH Blum. 2000. Food security and crop productivity in Kathmandu valley/Nepal. In: Proceeding of International Workshop in Food Security of Urban and Peri-urban Systems in Developing Countries, 15-18 November 2000. Vienna, Austria. Pp. 28-31.

Karki KB, KB Thapa and P Karki. 2005. Tea and coffee growing soils of Nepal. In: Proc. National Workshop on Commercial Crop for Poverty Alleviation in Nepal. (In Press).

Karki KB. 2004. Status of potassium in intensively cultivated soils from Kathmandu Valley. Nepalese J. Sci. and Tech. 5:83-89.

Mengel K and EA Kirkby. 1987. Principles of plant nutrition. International Potash Institute, Bern, Switzerland.

Mengel K and Rahmatullah 1994. Exploitation of potassium by various crop species from primary minerals in soils rich in micas. Biol. Fertil. Soils 17:75-79.

Rao CS and AS Rao. 2000. Minimal exchangeable potassium status of 15 smectitic soils in relation to potassium, uptake and plant mobilization rate of soil reserve potassium. Communication in Soil Science and Plant Analysis 31:913-921.

Regmi AP, JK Ladha, E Pasuquin, H Pathak, PR Hobbs, LL Shrestha, DB Gharti and E Duveiller. 2002. The role of Potassium in sustaining yields in a long-term rice-wheat experiment in the Indo-Gangetic plains of Nepal. Biol. Fert. Soils 36:240-247.

Schneider A. 1997. Release and fixation of potassium by a loamy soil as affected by initial water content and potassium status of soil samples. European J. Soil Sci. 48:263-271.

Schrier H, PB Shah, LM Lavkulich and S Brown. 1994. Maintaining soil fertility under increasing land use pressure in the middle mountains of Nepal. Soil Use and Management 10:137-142.

Singh D, V Singh, R Singh, D Singh, V Singh and R Singh. 1997. Potassium status of soils and response of rice to applied potassium. J. Pot. Research 15:83-87.

Tsuno Y and K Fujise. 1998. An experiment of the determinant of mineral nutrient on the tuber yield of sweet potato. Proc. Crop Scie. Soc. 37:273-279. Japan.

Wulf F, V Schultz, A Jungk and N Claassen. 1998. Potassium fertilization in relation to soil test, crop yield and Kleaching. Z. Pflanzenernaerung Bodenk.161:591-599. 